\title{
CZECH-RUSSIAN (CZECHOSLOVAK-SOVIET) COOPERATION IN THE FIELD OF FORMATION AND DEVELOPMENT OF MUSEOLOGY AS A SCIENCE
}

\section{MARIA GUBARENKO}

\section{ABSTRACT/ABSTRAKT}

This article is a theoretical investigation of the Czech-Russian (Czechoslovak-Soviet) cooperation in the field of museology development. Although, the interconnection between the Czech and Russian schools of museology seems to be obvious, the emphasis is laid on the issues that have not been deeply studied yet. The author offers a historical overview of this relationship, focusing on the scientific contacts and its influence on the educational system. It provides the reader with a detailed coverage of personal archive materials of A. M. Razgon that have never been treated in scientific publications before. It is a unique survey for all those connected with museology.

Česko-ruská (československo-sovětská) spolupráce v oblasti formování a rozvoje muzeologie jako vědy

Tento článek se zabývá problematikou česko-ruské (československo-sovětské) spolupráce v oblasti rozvoje muzeologie. I když vzájemné propojení české a ruské muzeologické školy je zřejmé, důraz je kladen na problémy, které doposud nebyly podrobně zkoumány. Autorka podává historický přehled vzájemných vztahů a zaměřuje se na vědecké kontakty a jejich vliv na vzdělávací systém. Zprostředkovává čtenářơm detailní přehled soukromých archivních materiálů A. M. Razgona, které nebyly dosud předmětem vědeckých publikací. Tato práce je tudíž velkým přínosem pro všechny, kdo se zajímají o muzeologii.

\section{KEYWORDS/KLÍČOVÁ SLOVA}

history of museology A. M. Razgon - Z. Z. Stránský ICOFOM - theory of museology museology as science - intellectual cooperation

historie muzeologie - A. M. Razgon Z. Z. Stránský - ICOFOM - teorie muzeologie - museologie jako vědaintelektuální spolupráce

\section{INTRODUCTION}

Currently in Russia museology is defined as "a scientific discipline that studies a specific man's attitude to reality and a caused by this attitude museum phenomenon; that investigates the process of preservation and transmission of social information through museum objects and examines the development of museum studies and the possible directions of museum activity." 1 The subject of museology science, as it is in Czech Republic, is the process of musealization of reality. ${ }^{2}$ Russian museology is closely related to the Czechoslovak one as it has largely adopted its conceptual framework, content and structure.

In the 1960s-1980s the Czechoslovak and Soviet museologists have been very actively and closely cooperated within the ICOM (Inter-

1 Rossiyskaya muzeynaya entsiklopediya [online]. Moskva, 2002 [cit. 2016-01-28]. Available from www: <http://www.museum.ru/rme/museology. asp $>$.

2 The definition of museology is given by Zbyněk Z. Stránský in his latest monograph STRÁNSKÝ, Zbyněk Z. Archeologie a muzeologie. Brno: Masarykova univerzita v Brně, 2005, p. 256. national Council of Museums) and ICOFOM (International Committee for Museology); they also took part in a large number of joint theoretical and scientific researches. From 1977 after the ICOFOM creation, on the initiative of ICOM President and Moravian Museum Director Jan Jelínek museology started to get acknowledged as an independent discipline with its own definition, object, subject, vocabulary, method and structure. The main stages in the establishment of museology as a science can be defined as follows: the proto-museological or pre-scientific stage in the $18^{\text {th }}-$ mid $20^{\text {th }}$ century; the dynamic development of museology as an independent field of study from the beginning of 1960s until 1989; the evolution of museology as an academic and scientific discipline. The chronological scope of this article is limited by the second stage as is evident from its title. The source basis of this article is mainly composed by the archive materials of the Russian State Historical Museum, an important centre for museum studies.

The Czech scientists have greatly contributed to the development of the theoretical aspects of museology and the establishment of the first academic museological course for university students. The main theorist in the field of museology who played a significant role in the development and establishment of museology as an independent discipline was Z. Z. Stránský (19262016). The work of Czech scientists J. Neustupný (1905-1981), J. Beneš (1917-2005) and Stránský, had influenced many researches and 
museologists throughout the world - it is difficult to find an article that doesn' $t$ mention the ideas of these outstanding Czech museologists. That influence has also significantly impacted the evolution of museology in Russia.

\section{The first professional scientific contacts in the field of museum studies (the end of the $19^{\text {th }}$ centu- ry - first half of the $20^{\text {th }}$ century). Development background of $\mathrm{mu}$ - seology as a science}

The participation of scientists in the activity of the oldest museum organization, created in 1898 (Association of Museum Workers in Defense Against Counterfeiting and Unfair Trade Practices ${ }^{3}$ ) can be considered as the beginning of their professional contacts in the field of museum studies. It was mostly comprised of German museum workers but among the members there were also 3 representatives from Russia and 11 from Austria-Hungary. The meetings of the Association were held in several cities, and in 1913 the meeting was held in Russia (in Saint-Petersburg with a visit to Moscow).

During the first half of the $20^{\text {th }}$ century the Soviet museologists practically didn' $t$ take part in the work of the International Bureau of Museums (Office International des Musees) as that organization consisted only of the members of the League of Nations and the USSR didn' t belong to this organization at that time. J. Špét underlined that the world's acknowledgement of museology as a specific discipline started in Western Europe after World War I and that the creation of International Bureau of Museums can be considered as the official

3 About this association see: KIRSCH, Otakar. Association of Museum Workers in Defense Against Counterfeiting and Unfair Trade Practices: comments on the origins of organized meetings of museum workers on an international basis. Museologica Brunensia, 2015 , vol. 4 , no. 2 , pp. 48-55. birth of this field of study. ${ }^{4}$ However, we know some cases of USSR participation in this process. For instance, the article by F. I. Schmidt entitled "The Museums of USSR" was included into first largest international collection "Museums: International Research on the Reformation of Public Galleries' issue" and was considered to be one of the most important in the volume. ${ }^{5}$ Moreover the People's Commissar for Education A. V. Lunacharsky often attended the sessions of the International Committee on Intellectual Cooperation. ${ }^{6}$

During wartime all international contacts on the issue of museology were cut off. They were renewed immediately after the end of the World War II resulting in the creation of two organizations: UNESCO with its museum section, inheriting the International Bureau of Museums, and ICOM.

After the WWII, USSR didn' t maintain international contacts in the field of museology. ${ }^{7}$ The only contribution of Soviet museologists to the international community's work in this field consisted of some articles published in foreign magazines. ${ }^{8}$ After the establishment of the socialist regime in Czechoslovakia in

\footnotetext{
4 ŠPÉT, Jiří. Muzea ve vývoji společnosti a národní kultury. Praha: Národní muzeum, 1979, p. 22. 5 P. E. d., G. H. Avant-Propos//Musees. Paris, 1931, p. 9. (Les Cahiers de la Republique des lettres, des sciences et des arts. Vol. XIII); ANANIEV, Vitaly. Fedor Ivanovich Shmit i sbornik Muzei: Mezhdunarodnoe issledovanie po voprosu reformy publichnykh galerey (1931 g.): u istokov muzeynoy revolyutsii. Voprosy muzeologii, 2012, vol. 6, no. 2, p. 190.

6 LAQUA, Daniel. Transnational intellectual cooperation, tha League of Nations, and the problem of order. Journal of Global History, 2011, vol. 6, pp. 223-247; ANANIEV, Vitaly. Istoriya formirovaniya i osnovnye napravleniya deyatel'nosti mezhdunarodnogo byuro muzeev. Vestnik RGGU. Seriya Kul'turologiya. Iskusstvovedenie. Muzeologiya, 2012, vol. 91, no. 11, p. 225.

7 Russia only joined UNESCO on 12. 05. 1954, ICOM in 1957, it has been a member of ICOFOM since its inception in 1977 as one of its founders was Russian museologist A. M. Razgon, PhD.

8 See, for example, the article mentioned by $\mathrm{Ne}$ ustupný: DOROKHOV, A. Moscow Gallery cooperates with schools in educational work. The Museums Journal, 1947, no. 12, pp. 239-240.
}

1945 the USSR's impact on museology has increased. The socialist ideology penetrated into all spheres of life including museum studies and science. Nevertheless Russian museologist V. G. Ananiev notes that this influence was rather in the institutionalization of museology than in its content. ${ }^{9}$ Czech museologist P. Douša states that after 1945 Czechoslovak museology attempted to recreate the Soviet model of museum organization and management. ${ }^{10}$

In 1940s-1950s started the active implementation of an ideologically charged approach to the museological texts in Czech Republic. The message "Museums serve people" provides an excessive evidence of existent ideology. The education of the working class became the first and foremost goal of the museums. The Soviet museums in the museological literature are often considered as an example of successful scientific and educational practice. There is an entire chapter in the publication "Museums of USSR as an example of museum operation" devoted to them. ${ }^{11}$

Czechoslovakia was one of the main members of UNESCO as well as ICOM that was created under it. The active participation of Czechoslovakia in these organizations started to develop after USSR joined UNESCO and ICOM in 1954. ${ }^{12}$

\footnotetext{
9 ANANIEV, Vitaly. Chekhoslovatskaya shkola v muzeologii. In ANANIEV, Vitaly G. Istoriya zarubezhnoy muzeologii: uchebno-metodicheskoy posobie. Sankt-Peterburg: Institut istorii S.-Peterb. gos. un-ta, 2014, p. 69

10 DOUŠA, Pavel. Organizace českého muzejnictví 1945-1989. Opava: Slezská univerzita v Opavě, Filozoficko-př́rodovědecká fakulta, Ústav historie a muzeologie, 2005, p. 93. Ph.D. Thesis.

11 DENKSTEIN, Vladimír, František MATOUŠ and Karel TUČEK. Musea slouží lidu: Př́ručka pro musejní a vlastivědné pracovníky. Praha: Orbis, 1954, pp. 36-39.

12 DOUŠA, Pavel. Organizace českého muzejnictví 1945-1989. Opava: Slezská univerzita v Opavě, Filozoficko-přírodovědecká fakulta, Ústav historie a muzeologie, 2005, p. 53. Ph.D. Thesis.
} 
In $1951 \mathrm{~J}$. Neustupný stated that the USSR's non-participation in the work of UNESCO and ICOM had an adverse effect on the development of museology as, from his point of view, the museum practices in the USSR were very progressive. ${ }^{13}$ Especially he highlighted the work of the Research Institute for Regional History and Museum Practice of the Committee for the Cultural and Educational Institutions in RSFSR under the Sovnarkom, as a museology centre that published instructions and recommendations on museum work. J. Neustupný repeatedly underlined the innovative views of his Soviet colleagues while highly valuing the vast museum network in the USSR. According to J. Neustupný, in addition to carrying out scientific researches museum should efficiently educate the public. While thinking over the definition of museology (whether it's a scientific discipline or a technique) Neustupný quoted Soviet museologists G. N. Serebrennikov and others. ${ }^{14}$ In his next monograph he again quoted the publications of Soviet scientists ${ }^{15}$ and in particular the textbook "The Basics of Soviet Museum Studies" published in Moscow in 1955 as well as commented on the definitions of the terms "science" and "museology" given by A. M. Razgon in the Great Soviet Encyclopedia in 1954 and the work of other authors. ${ }^{16}$

13 NEUSTUPNÝ, Jiří. Otázky dnešního musejnictví: příspěvky k obecné a speciální museologii. Praha: Orbis, 1950, p. 19.

14 In NEUSTUPNÝ, Jiří. Otázky dnešního musejnictví: př́spěvky $k$ obecné a speciální museologii.

Praha: Orbis, 1950, p. 5, he quotes Serebrennikov's book „Organizatsiya i soderzhanie nauchno-issledovatel'skoy raboty muzeev“, Moskva, 1945. Neustupný notes that the books by D. A. Antonov, O. T. Kozlov, D. Manevsky, Y. A. Almazov, N. N. Plavilshchikov weren't available in Prague at the moment (1950).

15 NEUSTUPNÝ, Jiří. Muzeum a věda. Praha: Národní muzeum, 1968. See: Notes no. 5 to chapter 1 ; no. $5,10,12,17,22$ to chapter 2 ; no. $7,10,15$ to chapter 4 ; no. $2,4,6,11,19,22$ to chapter 5 ; no. 4 to chapter 6 ; no. $4,5,6,7$ to chapter 7 ; no. 4 to chapter 8 ; no. 2,3 to chapter 9 ; no. $4,13,18,32$ to chapter 11 .

16 KOPNIN, P. V. „Logika nauchnogo issledovaniya“. Moskva, 1965; KELLE, V. Z. and M. L. KOVAL‘ZON „O klassifikatsii obshchestvennykh
In the chapter "Museums of USSR as an example for our (Czechoslovak - author) museums" in Denkstein's and Tuček's book on the structure of regional museums in Czech Republic and USSR it is mentioned that Soviet museums can provide a good example of the organizational, pedagogical and educational function realization. ${ }^{17}$ Was such intensified attention to museum studies in USSR and the high recognition of Czech museologists a strictly professional opinion or did the political situation in the country influence the contents of their texts? It is likely that both suppositions are correct.

In the 1950s we can see not only the bilateral acquaintance of Czech and Soviet museologists but also the beginning of direct contacts, professional correspondence and cooperation between them. For example, during the creation of the Prehistoric Czechoslovakia exhibition in Prague J. Neustupný who was the Head of the Artifacts History Department of the National Museum in Prague asked the State Hermitage Museum to give him for this exposition 14 casts of Scythian objects. ${ }^{18}$ The common ground of museological principles provided a basis for cooperation. ${ }^{19}$

\footnotetext{
nauk". Voprosy filosofii, 1964, no. 11; the articles by E. Sil'versvan, M. Faktorovich, N. V. Mints, N. Sharun, O. Lyaskovskaya, G. Chepelevetskaya in Trudy NII muzeevedeniya „Nauchnaya rabota $v$ khudozhestvennykh muzeyakh“, vyp. 17, Moskva, 1965, 252 r.; A. I. Mikhaylovskaya „Muzeynaya ekspozitsiya. Organizatsiya i tekhnika“ in Trudy NII muzeevedeniya, vol. 17, Moskva, 1964; M. G. Rabinovich „Arkheologicheskie materialy v ekspozitsii kraevedcheskikh muzeev“ in NII muzeevedeniya, M., 1961; V. M. Raushenbakh "Arkheologicheskie materialy v ekspozitsii kraevedcheskikh muzeev" in NII kraevedcheskoy i muzeynoy raboty, Moskva, 1954; Z. A. Ogrizko „Metodika postroeniya ekspozitsii po istorii SSSR“ in NII muzeevedeniya, M., 1965).

17 Chapter Museums of USSR as an example for our (Czechoslovak - author) museums - DENKSTEIN Vladimír, František MATOUŠ and Karel TUČEK. Muzea slouží lidu. Příručka pro musejní a vlastivědné pracovníky. Praha: Orbis, 1954, pp. 36-39.

18 ANANIEV, Vitaly. K 105-letiyu Jiri Neustupnogo: Neizvestnye pis'ma iz arkhiva Gosudarstvennogo Ermitazha. Muzey, 2010, no. 8, p. 69.
}

19 Idem, p. 70.
Many scientists spotlight that museology has an international nature, for example, J. Beneš notes "No one state will create the museological system in isolation since none have enough specialists to create it as a unique system of reality $\operatorname{cog}$ nition. Therefore the solution can only be found in the international cooperation of willingful museologists throughout the world."20

In the late 1954-early 1955 thanks to the Ministry of Culture of CSR, a five-week educational visit of the Czechoslovak delegation of $4 \mathrm{mu}$ seum workers to USSR took place. ${ }^{21}$ The delegation visited Moscow, Leningrad and Kiev. The visit resulted in the publication of the book "Museum practice in USSR" written by the delegation's leader K. Tuček, Head of the Museums Department of the Ministry of Culture, and the further development of interpretation and the implementation of museum practice experience as it can be seen in the work "Guidelines for the research fellows at the state governed museums" published in 1955. That visit had also a crucial influence on the foundation of the Museological Cabinet in Czech Republic in $1955^{22}$ and what is more it made the participants familiar with the useful research of the Museum Studies Research Institute (currently known as the Russian Culturology Institute) in Moscow.

\footnotetext{
20 BENEŠ, Josef. Základy muzeologie. Opava: Open Education \& Sciences pro Ústav historie a muzeologie Filozoficko-přírodovědecké fakulty Slezské univerzity, 1997, p. 156.

21 The delegation was led by K. Tuček, Head of the Museums Department of the Ministry of Culture and included J. Šufliarský, Head of Museums and Landmarks Department, E. Poche, Director of the Museum of Industrial and Applied Arts in Prague, F. Frantl, Deputy Director of the National Museum in Prague. See DOUŠA, Pavel. Organizace českého muzejnictví 1945-1989. Opava: Slezská univerzita v Opavě, Filozoficko-přírodovědecká fakulta, Ústav historie a muzeologie, 2005, pp. 92-94. Ph.D. Thesis.

22 V. Pubal (1913-1992) attributes the Cabinet's foundation to that visit in particular. PUBAL, Václav. Kabinet musejní a vlastivědné práce. Časopis Národního muzea, 1957, vol. 126, no. 2, p. 231.
} 
In 1955 took place the exchange of museological literature between the Ministries of Culture of the two countries followed by the Czech translations of the Soviet museologists' works. ${ }^{23}$

\section{The 1960s: museology starts emerging as a science}

Museology started to form itself and became recognized by the international professional community as an independent scientific discipline in 1960s. That time saw the first contacts of Soviet and Czeckoslovak scientists in this field. Research in museology and international museum cooperation were initiated by the Czech Central Museological Cabinet. The Cabinet worked together with many foreign institutions including the Cultural Research Institute in Moscow. The cooperation included core publication exchange and foreign internship programs' organization.

At the same time the Moravian Museum in Brno established itself as the museological center of Czechoslovakia where Z. Z. Stránský founded the special methodological centre for theoretical museology.

Starting from 1960s Z. Z. Stránský consecutively clarified and proved that museology was a scientific discipline by formulating a whole theory. ${ }^{24}$ Stránský examined the common characteristics of an independent scientific discipline: its possible subject, its structure and method. When Z. Z. Stránský was thinking over the theory of the

23 M. P. Simkin „Sbor materialov iz sovetsko go vremeni“. Praga, 1955; M. V. Farmakovskiy „Konservatsiya i okhrana muzeynykh kollektsiy“. Praga, 1955; A. I. Mikhaylovskaya "Organizatsiya i tekhnika muzeynoy vystavochnoy deyatel'nosti“. Praga, 1953. Also see DOUŠA, Pavel. Organizace českého muzejnictví 1945-1989. Opava: Slezská univerzita v Opavě, Filozoficko-přírodovědecká fakulta, Ústav historie a muzeologie, 2005, p. 94, note no. 295. Ph.D. Thesis.

24 His work in museology reaches its peak in his latest monograph „Archeologie a muzeologie“ published in 2005 in Brno. subject of museology, in 1965 at the museological symposium, Stránský noted that museum itself cannot serve as the subject of museology. Stránský criticized an approach to the structure of museology analyzing the soviet textbook "The Fundamentals of Soviet Museum Studies". "We have shown that the Soviet compendium of museology is a complex knowledge concerning a museum as a subject of study. But structure cannot be just a complex of subjects or knowledge but is in fact that limits it..."25

While studying Czech-Russian professional contacts in the field of museology specific attention should be paid to the correspondence between ICOFOM vice-president A. M. Razgon ${ }^{26}$ and his foreign colleagues in the late 1970s-early 1980s. A. M. Razgon maintained professional contacts with Czechoslovak museologists and members of ICOM including Z. Stránský, J. Jelínek, M. Rybecký, J. Pernes, K. Schreiner and others. Sometimes they communicated informally as it was, for instance, with Z. Z. Stránský. ${ }^{27}$ The remaining letters of that period tell us about great mutual interest of Czechoslovak museologists in the cooperation with their Soviet colleagues. Although the most frequent issues in these letters are organizational issues and expressions

25 STRÁNSKÝ, Zbyněk Z. Podstata muzeologie a její zařazení do vysokoškolského studia In Sborník materiálů prvého muzeologického sympozia. Brno: Moravské muzeum, 1966, p. 14.

26 A. M. Razgon specialized in Russian 18th century history, historiography, museum studies and theoretical museology history. He worked as Deputy research Director at the Research Institute of Museum Studies (1953-1972), as Head of museology department at the Central Museum of Revolution (1972-1974). He was a lecturer at the Central Institute of Advanced Training of the Ministry of Culture of USSR, at Moscow State University. Doctoral thesis: History museums in Russia in 1861-1917. Razgon's theoretical work in museology served as a basis for several regulatory acts passed by the Ministry of Culture of the Russian Federation.

27 A greater part of foreign correspondence with ICOM members from that period has survived and is stored at the NHM's Department of Written Sources. of gratitude, theoretical problems of a young science are also discussed there.

The first remaining letter from Stránský to Razgon found in the NHM archives is dated 1973 when the scientists most likely hadn' $t$ yet met each other personally. Stránský wrote that Sofia Karahanyan had informed him of "Razgon's work and his interest in museology." 28

It should be mentioned that in one of the letters Stránský wrote about his intention to visit USSR and Razgon replied: "You are better known to USSR specialists than any other foreign museologist." 29

In 1970s-1980s Soviet museology actively incorporated, analyzed and absorbed the achievements of foreign museologists. ${ }^{30}$ In 1970 J. Neustupný presented his report "Historical framework of an archeological exhibition"31 at ICOM's History and Archaeology Museums conference ${ }^{32}$ in Moscow and Leningrad.

In 1971 Razgon met with E. Schneider who was the Director of Southern Czech Museum in České Budějovice. According to Schneider, Razgon's position was to a large extent similar to Czech views on museology and to the curriculum

28 Department of Written Sources The State Historical Museum, 546 - Personal files of A. M. Razgon, file. 283, letter from Stránský to Razgon. Brno on July 26, 1973.

29 Department of Written Sources The State Historical Museum, 546 - Personal files of A. M. Razgon, file 280, letter from Razgon to Stránský. Moscow on March 24, 1979.

30 KAULEN, Mariya. Uchebnik muzeevedeniya kak svyazuyushchee zveno mezhdu teoriey i praktikoy. In MINENKO, G. N. (ed.). Kul'turologiya $v$ teoreticheskom i prikladnom izmereniyakh: Mate rialy nauch.-prakt. Seminara. Kemerovo, Moskva: Rossiyskiy institut kul'turologii i Kemrovskiy gos. inst iskusstv i kul'tury, 2001, p. 256.

31 See NEUSTUPNÝ, Jiří. Istoricheskaya kontseptsiya arkheologicheskikh ekspozitsiy [B.m. B.g.] (Mashinopisnyy tekst na 8 skreplennykh listakh)// Biblioteka RAN. Shifr: 1970 g./764.

32 ANANIEV, Vitaly. K 105-letiyu Jiri Neustupnogo: Neizvestnye pis'ma iz arkhiva Gosudarstvennogo Ermitazha. Muzey, 2010, no. 8, p. 68. 
of the Department of Museology in Jan Evangelista Purkyně University in Brno. ${ }^{33}$

An abundance of foreign literature found in A. M. Razgon's personal archive including some articles, journals and monographs demonstrate us his deep interest in the work of his foreign colleagues. Razgon himself deeply studied and translated foreign museological literature as it can be evident from his participation in translations of more than 80 specialized museological articles written by Czech authors. ${ }^{34}$ Among the works of Czechoslovak museologists that had been translated in 1960s-1980s were the articles by J. Beneš, ${ }^{35}$ Z. Z. Stránský ${ }^{36}$ (with multiple comments by Razgon), J. Jelínek, ${ }^{37}$ A. Gregorová, ${ }^{38}$ J. Ka-

33 Department of Written Sources The State Historical Museum, 546 - Personal files of A. M. Razgon, file 283, letter from Stránský to Razgon. Brno on July 26, 1973.

34 These translations are stored at Department of Written Sources The State Historical Museum, 546 - Personal files of A. M. Razgon.

35 Department of Written Sources The State Historical Museum, 546 - Personal files of A. M. Raz gon, file 255 - J. Benes's articles 1965-1974; file 256 - J. Beneš's articles 1976-1980; cart. 257-258 J. Beneš's articles 1980-1983, article „Vklad muzeevedeniya $\mathrm{v}$ razvitie muzeynogo dela“.

36 Department of Written Sources The State Historical Museum, 546 - Personal files of A. M. Razgon, file 266 - there are total 9 Z. Z. Stránský's articles in this file, included „Osnovy obshchego muzeevedeniya" from journal Muzeologické sešity. Brno, 1971, pp. 40-46; „Ponimanie muzeevedeniya“, 1979; translation German by Razgon; Z. Z. Stránský's article „Zur auffassung der museologie“ /Diskussionsmaterial/ Als Handschrift vervielfaltigt, Brno 1966; article translation from Bulgarian by Z. Z. Stránský "Muzeologiya kak nauka" Sofia, 1981; article translated from English "Sistema muzeevedeniya" Moscow, 1982.

37 Department of Written Sources The State Historical Museum, 546 - Personal files of A. M. Razgon, file 261, J. Jelínek „Regional'nye muzei i nauchnaya rabota v muzeyakh" 1970 .

38 Department of Written Sources The State Historical Museum, 546 - Personal files of A. M. Raz gon, file 260, A. Gregorová „Muzey i muzeynoe delo“. pitola, ${ }^{39}$ L. Kunz, ${ }^{40}$ J. Neustupný, ${ }^{41}$ J. Špét. ${ }^{42}$ It should be highlighted that yet none of these monographs have been translated into Russian.

Several articles written by Czech museologists were published in journals and digests. ${ }^{43}$ On the other hand, Soviet museologists' articles were published in Czech periodicals such as "Museological Papers" of the Moravian Museum in Brno. Among Soviet publications with foreign (including Czech) participation we can mention the digests of the Research Institute of Museology. ${ }^{44}$

\section{Z. Z. Stránský studied Razgon's} publications in Soviet editions. ${ }^{45}$ In their turn, in 1970s his Czech colleagues sent their own publica-

39 Department of Written Sources The State Historical Museum, 546 - Personal files of A. M. Razgon, file 260, J. Kapitola „Muzeum a skutočnost“.

40 Department of Written Sources The State His torical Museum, 546 - Personal files of A. M. Razgon, file 262, L. Kunz „Etnografii muzeevedeniya v sotsialisticheskom obshchestve", Muzeologické sešity, 1976, vol. 6 .

41 Department of Written Sources The State Historical Museum, 546 - Personal files of A. M. Razgon, file 264, J. Neustupný „Slozhnyy kharakter muzeeveedeniya", Muzeum1981, no. 1; J. Neustupný „Muzey i isssledovatel'skaya rabota 1968 g. iz zhurnala „Muzeum a věda“.

42 Department of Written Sources The State Historical Museum, 546 - Personal files of

A. M. Razgon, file. 269. J. Špét „Muzeologicheskie vzglyady Klimenta Čermáka“ 1977 from „Muzeum a vlastivědná práce“

43 For example: STRÁNSKÝ, Zbyněk Z. Ponimanie muzeevedeniya. In Muzeevedenie. Muzei mira (Sb. nauch. tr./NII kul'tury). Moskva, 1991, pp. 8-26; STRÁNSKÝ, Zbyněk Z. Muzey, iskusstvo i perspektivy razvitiya chelovechestva. In Muzey noe delo. Muzey - kul'tura - obshchestvo: sb. nauch. tr., Moskva: Izd-vo Muzeya revolyutsii, 1992, pp. 247-258; GRULICH, T. Regional'nye muzei i ikh $\mathrm{rol}^{\text {'v }}$ sovremennom obshchestve. In Muzeevedenie. Muzei mira (Sb. nauch. tr.), Moskva: NII kul'tury, 1991, pp. 287-293; ŽALMAN, I. O roli kraevedcheskikh muzeev Chekho-Slovakii v reshenii mestnykh i regional'nykh ekologicheskikh problém. In Muzeevedenie. Muzei mira (Sb. nauch. tr.), Moskva: NII kul'tury, 1991, pp. 294-297.

44 Muzeynoe delo. Muzey - kul'tura - ob

shchestvo: sb. nauch. tr. - Moskva: Izd-vo Muzeya revolyutsii, 1992. 276 p.; Muzeevedenie. Muzei mira, Moskva: Nauchno-issledovatel'skiy institut kul'tury, 1991, 384 p.

45 Department of Written Sources The State Historical Museum, 546 - Personal files of A. M. Razgon, file 283. letter from Stránský to Razgon. Brno on July 26, 1973. tions to A. M. Razgon at NHM and to the museological department of the Institute of Culture. They have also asked to send them some new articles written by Soviet museologists noting that they used to receive them more regularly and in greater numbers before $1979 .{ }^{46}$ On December 29, 1977 along with New Year greetings, Z. Stránský asked Razgon to confirm the translation and publication in the Methodical papers of the Moravian Museum of the dictionary that Razgon had sent him earlier. ${ }^{47}$ And in winter 1979 Z. Stránský informed him about the translation of the dictionary that had been already made and what is more about the translation and publication of Razgon's article on party membership in museology. ${ }^{48}$ Stránský himself wrote the introduction to these mentioned materials and published them in the "Neue Museumkunde" and the "Methodical Papers”. In 1981 Razgon sent Stránský the Abstract Digest of Informkultura where there was some material on several of Stránský's papers related to the questions of scientific documentation of the latest historical periods. He stressed out that he expected to systematically inform Soviet museologists about Stránský's work. ${ }^{49}$ In 1982 J. Pernes who became the Head of the Methodical Centre of Museology at the Moravian Museum in Brno after Stránský due to reorganization, had sent Razgon some J. Špét's monographs on the history of Czech museums, J. Beneš's "Museum and collections"

46 Department of Written Sources The State Historical Museum, 546 - Personal files of A. M. Razgon, file 283, letter from Stránský to Razgon. Brno on winter, 1979

47 Department of Written Sources The State Historical Museum, 546 - Personal files of A. M. Razgon, file 283, letter from Stránský to Razgon. Brno on December 29, 1977.

48 Department of Written Sources The State Historical Museum, 546 - Personal files of A. M. Razgon, file 283, letter from Stránský to Razgon. Brno on 1979.

49 Department of Written Sources The State Historical Museum, 546 - Personal files of A. M. Razgon, file 283, letter from Razgon to Stránský. Moscow on April 10, 1981. 
and other new Czech museological books. ${ }^{50}$

In 1983 , due to the 100th anniversary of the publication of I. G. T. Grasse's article "Die Museologie als Fachwissenschaft" in "Zeitschrift für Museolgie und Antiquitätenkunde", the "Museological Papers" editorial office workers posed questions ${ }^{51}$ on the essence of museology and its status as a science to several notable museologists. The journal published the answers of Soviet museologists A. Razgon and A. Zax. ${ }^{52}$ In his response Razgon notes that "there is yet a lot to be done in museology... However thanks to the efforts of museologists and in particular those that came from socialist countries, including such noticeable Czechoslovak museologists as Z. Z. Stránský, J. Beně̌, J. Neustupný and J. Špét, the systematization of museological knowledge and its self-cognition as a science have significantly stepped forward." 53

"Bibliographie museologique internationale ICOM" was one of the projects in which Soviet museologists participated. It was being published from 1969 to 1980 by Czechoslovakia together with the documentary centre of UNESCO-ICOM. In the 1970s Soviet museologists took part in this Czechoslovak edition while providing it with the bibliography in the languages of USSR nations. By 1979 this practice has stopped and A. M. Razgon has underlined the sharp necessity of Soviet participa-

50 Department of Written Sources The State Historical Museum, 546 - Personal files of A. M. Raz gon, file 283, letter from Pernes to Razgon.Brno on May 2, 1982.

51 Department of Written Sources The State Historical Museum, 546 - Personal files of A. M. Razgon, file 283, letter from Stránský (from edition of Muzeologicke sesity) to Razgon. Brno.

52 Mezinárodni anketa. Muzeologické sešity, 1983, vol. 9, pp. 9-55

53 Mezinárodní anketa. Muzeologické sešity, 1983, vol. 9, p. 42 tion renewal in this valuable international publication. ${ }^{54}$

\section{The creation of ICOFOM}

The creation of the International Committee for Museology was an important milestone in the formation of museology as a scientific discipline. ICOFOM was founded in 1977 at the 11th General Conference of ICOM at the initiative of J. Jelínek. The first session of ICOFOM was held on 19-23 May 1977 in Leningrad. A. M. Razgon, ICOFOM vice-president, replying to Jelínek's letter and commenting on the first session of ICOFOM, wrote "I am still convinced that with time ICOFOM can and will become that center that holds up and guides the relatively loose structure of ICOM's committees to which activity you've so greatly contributed recently." 55 Razgon emphasized the importance of clear formulation of the Committee's activities conception and its realization. He also criticized G. H. Rivière for his "ephemeral suggestions" that couldn' t be trusted and whose methods were unacceptable for museologists from socialist countries. ${ }^{56}$

In 1979 ICOM included a significant number of Eastern European museologists and many members of ICTOP were very confused by this fact. ${ }^{57}$ At the joint meeting of these two committees in 1983 J. Barkow, a member of ICTOP had announced these concerns. He expressed his opinion on the influence that the museologists from socialist coun-

54 Department of Written Sources The State Historical Museum, 546 - Personal files of A. M. Razgon, file 23, sg. 4. Razgon's article „Mezhdunarodnoe sotrudnichestvo $\mathrm{v}$ razrabotke problem muzeologii. 1979. This article was published in „Kirgistan“ Frunze (?) in 1982.

55 Department of Written Sources The State Historical Museum, file 546 - Personal files A. M. Raz gona, cart. 280. Letter from A. M. Razgon to J. Jelínek. Moscow on August 15, 1977.

56 Idem, file 280 .

57 International Committee for the Training of Personnel. tries had in ICOFOM. From his point of view the chief worry was the Czech influence (it can be seen even in the topics and in the title of the journal) that was connected with the name of Stránský. Though his evident fear of the socialist dominance in the museological discourse maybe was exaggerated, statement - "while for socialist countries' representatives the proposed topic (whether museology is a science or not) doesn' $t$ pose any problem... the members from Western countries have to talk a lot, to avoid any questions or to reply on them not very deeply" had a certain scence. All in all, P. van Mensch concludes, what is evident is the lack of understanding of the Committee's scientific purposes and the unwillingness to raise the higher level discussions. ${ }^{58}$

The share of Eastern European museologists declined with time. In 1977-1989 there was a change in the composition of the Committee Council which had shifted from mostly socialist and French-speaking to Western European and English-speaking members. In 1983-1989 Stránský was one of 12 members of ICOFOM that constituted the main part of the Committee. During that period many Eastern Europeans took part in the work of ICOFOM. However these years 1983-1989 were the peak years for Eastern European participation in the Committee work after which their participation in ICOFOM's activities started to decline. ${ }^{59}$

The cooperation between museologists became closer because of their work in ICOM and ICOFOM that coordinated their theoretical efforts in the field as well as at the inter-

58 VAN MENSCH, Peter. K metodologii muzeologii (perevod s angl. yaz. V. G. Anan'ieva). Voprosy muzeologii, 2014, vol. 9, no. 1, pp. 15-291 [online]. [cit. 2016-08-22] Available from www: <http:// cyberleninka.ru/journal/n/voprosy-muzeologii>

59 This article doesn't cover the work of V. Sofka as in 1968 he emigrated from Czech Republic and he is Sweden citizen. 
national conferences. The archive documents broaden our knowledge about professional meetings between Razgon and Stránský during the ICOFOM's working group session in Gera, Germany in 1977.

The annual symposiums were the main form of the Committee's activity. The recognition of museology as an independent scientific discipline became possible due to the discussion of acute problems on those conferences and symposiums. The Committee's publications also played a significant role in the distribution of museological knowledge. ${ }^{60}$

An international cooperation in the development of museological issues, in the work of ICOM international committees, special theme conferences and expert groups became widespread. For instance, ICOFOM presented a working group that was responsible for making a program plan of various acute scientific publications in the field of museology and for the collection and publication of the documents. The members of that group were G. Dissner, V. Klausewitz, A. Razgon and V. Sofka.

Razgon participated in all the symposiums in the first period of 1977 to 1982 while Stránský attended in the second period of 1983 to $1989 .{ }^{61}$ In one of his reports in 1979 Razgon highlighted the importance of these conferences organized by ICOM and its Committees as he wrote that "the committee work is very useful in terms of professional contacts, museum practices experience and the cur-

60 See TRUEVTSEV, Nikolay. Istoriya obrazovaniya i deyatel'nost' komiteta muzeologii mezhdunarodnogo soveta. Barnaul: FGBOU VPO, Altayskaya gosudarstvennaya pedagogicheskaya akademiya, 2012. 214 p.

61 VAN MENSCH, Peter. K metodologii muzeologii (perevod s angl. yaz. V. G. Anan'yeva). Voprosy muzeologii, 2014, vol. 9, no. 1, p. 54. [online]. [cit. 2015-08-22] Available from www: <http://cyberleninka.ru/journal/n/voprosy-muzeologii >. rent state of research." ${ }^{12}$ However he once again underlined the lacking activity of Soviet museologists in a number of international projects. As the first period ended several key members of the committee including Razgon and Jelínek left the Committee as well as the ICOFOM Council.

The new three-year plan of the Committee's work was adopted at the 1977 session in Moscow. ${ }^{63}$ It included all the main aspects of further international cooperation. The Committee focused its attention on the "study of theoretical aspects of the problem...rather than the practical applications." ${ }^{\prime 4}$ The decision to create a generalizing theoretical work - the museology textbook was also taken at this first ICOFOM session.

The idea of textbook's creation appeared even earlier. Its necessity was realized in the early $20^{\text {th }}$ century and the International Museum Office of the League of Nations attempted to publish several volumes of Museographie I and II in 1934. However, as it was underlined by Razgon the development level of the field's was a true obstacle for this idea realization.

\section{At the initiative of UNESCO's} a group of experts from several countries chaired by G. Rivière gathered in Paris from the 30th of August until the 1st of September 1977 to discuss the museology textbook preparations. M. Monescu's (Romania) report provides an overview of the project. "The book should be in the format of a textbook

62 Department of Written Sources The State Historical Museum, file 546 - Personal files A. M. Raz gona, cart. 242, sg. 13-15.

63 About founding of ICOFOM see Archiv Moravského zemského muzea v Brně, file Moravské zemské muzeum - Jelínek, ICOM, file 438/77.

64 File no. 76 A/B on June 15, 1976 from TRUEVTSEV, Nikolay. Istoriya obrazovaniya $i$ deyatel'nost' komiteta muzeologii mezhdunarodnogo soveta. Barnaul: FGBOU VPO, Altayskaya gosudarstvennaya pedagogicheskaya akademiya, 2012. defining the principles and methods of museology as an independent discipline. It shall be a textbook on both museology and museography so that the balance between theory and practice is kept. The textbook should... formulate the principles of museology on a historical basis, its specific methods and everything that influenced its establishment as an independent scientific discipline." 65 The structure of the book was ready and it was supposed that this work will include 5 volumes and will be published in English and French. Actually, it was the first attempt to create an international fundamental museological book where different chapters were supposed to be written by different scientists all over the world. At the same time, along with the textbook, it was considered to work at the creation of the Museological Dictionary of Technical Terms.

\section{In 1972, ICOM Secretariat session} featured a discussion on Rivière's "Topic", that developed project of "Museology treatise". The chosen editors of each volume were: Rivière, Jelínek, Singletone, Oddon, Stolov. Therefore only one-fifth of them were representatives from socialist countries (from Czechoslovakia) and, according to Razgon's assumption, even that was because Jelínek was the President of ICOM at the time. This project of the generalized collective museological treatise anyhow wasn' $t$ realized. In 1977 at the ICOM conference this project wasn' $t$ even mentioned and the participants focused instead on UNESCO's proposed museology work that was supposed to be written by H. Hudson.

A second attempt to create such a generalized text was made in 1977. ICOM’s President Jan Jelínek

65 Department of Written Sources The State Historical Museum, 546 - Personal files of A. $M$. Razgon, file 242, sg. 1-2. Protocol of the meeting was made by a group of specialists in order to prepare a textbook on muzeology 30 August-1 September 1971 in Paris. 
had set the Committee a task to create a conception for the work "The Fundamentals of Museology", the Czechoslovak project structually similar to the UNESCO one.

In September, 1977, Jelínek sent Razgon a very brief and underdone version of this book entitled "Treatrise of museology"66 (the same title by the way had the second working group in which on the first ICOFOM session participated Razgon) and asked him to comment on the structure and to expand or to change the content of each chapter. ${ }^{67}$ Jelínek underlined that every chapter would be written by an individual specialist and asked Razgon to share his opinion on the selection of authors. Razgon had sent an answer to Jelínek (on 2 and a half lists of paper) with a result of his structural analysis of the book. Razgon wrote that he considered this project very interesting and that "the project contains lots of elements that were proposed, even by me, in 1968, and then were again announced in the report made at the expert conference in Paris, Popescu, that was mentioned in 1971." 68

Razgon suggested changing the title of the second chapter from "History of museum practices" to "Museum, its genesis and social functions", 69 expanding the title of another chapter from "Collection acquisition" to "Collection acquisition, description and study". Overall Razgon proposed to broaden the range of

66 Razgon notes his ,inability to understand the concise text of the project" (See Department of Written Sources The State Historical Museum, 546 - Personal files of A. M. Razgon, file 280, letter from A. Razgon to J. Jelínek. Moscow on March 3,1978 .

67 Department of Written Sources The State Historical Museum, 546 - Personal files of A. M. Razgon, file 281, letter from J. Jelínek (ICOM) to A. M. Razgon. Brno on September, 27, 1977.

68 Department of Written Sources The State Historical Museum, 546 - Personal files of

A. M. Razgon, file 280, letter from A. M. Razgon to J. Jelínek. Moscow on October 3, 1978.

69 In his 1988 textbook he uses a similar chapter title History museum in a socialist society, its role and social functions. raised issues, adding a separate chapter on the educational function of museums and to involve Asian, African and Latin American colleagues in the creation of chapters concerning museum practices in their countries. Razgon also made a proposal to add something about the connection of museums and cultural heritage protection. 20 years later J. Beneš will publish the first chapter devoted to the cultural heritage and museum practices in his 1997 work on museology "Základy muzeologie".

The Czechoslovak work "Fundamentals of Museology" hasn' t been ever written or published. This unpublished book's materials were used as a structural basis for the Soviet "Fundamentals of Museology" textbook as it was pointed out by Razgon. The textbook raised the issue of museology's theoretical aspects, the museum's social functions and its essence. Particular attention was paid to the collection formation and storage and the use of museum objects in the course of educational programs. Razgon explained the similarities in the textbooks structure. Firstly, he drew attention to the widespread discussion of the project within the socialist museological community. Secondly, he noted that the field's logical evolution dictated the necessity of adhering to that structure. Unfortunately this book has never been published and the manuscript is now stored at the NIIK archives. The unpublished contents of the 1960s "The Fundamentals of Museology" may have influenced the 1988 book "Museology. History museums" but this requires further examination.

ICOFOM symposium on "Research in museums: possibilities and limitations" became one of the most significant symposiums as it was related directly to define museol- ogy as a scientific discipline. ${ }^{70}$ It took place in Warsaw in 1978 and the USSR was represented by A. Razgon, the State Museum of the Arts director I. A. Antonova and the representative of the Ministry of Culture Vertogradova. Razgon's report on "Several theoretical aspects of the possibilities and limitations of museum research" was translated into Czech and French. ${ }^{71}$ We find it useful to present some of this report's statements. "While trying to examine museology as a science ...we rely upon the definition of science as a specific form of public consciousness that reflects objective reality that exists independent to our perception. ... Defining the possibilities and limitations of museum research isn' t possible without defining museology as a science, as well as without defining its subject, method and system. Depending on this definition all the research possibilities and what is more important all the limitations could be logically constructed. We do not yet have a canonical, universally accepted definition of the subject of museology even though quite a lot has been made to achieve that goal $7^{72}$ so we do not have any reason to feel inferior. We should honestly estimate the situation and the development level of our own science and we should accept that the representatives of other respected and acknowledged sciences often find themselves in a similar situation and they do not question themselves. I would only mention active debates found in academic

70 Archiv Moravského zemského muzea v Brně, file Moravské zemské muzeum, ICOM - Jelínek, ICOM, subfile 627/78, letter from A. M. Razgon to J. Jelínek. Moscow on August 22, 1978.

71 The text was sent to the organizers and to Jelínek. Department of Written Sources The State Historical Museum, 546 - Personal files of A. $M$. Razgon, file 22, sg. 44-59. This report hasn't been published in Russia. The Czech translation „Výzkumné práce v muzeu: možnosti a hranice” on 22 pages is stored at the Moravian Museum in Brno (see Archiv Moravského zemského muzea v Brně, file Moravské zemské muzeum, ICOM - Jelínek, ICOM. Moscow on November 2, 1978)

72 Refers to Stránský 1971, arcticle „Muzeevedenie" from Bol'shaya Sovetskaya Entsiklopediya. V 30 t. Vol. 17. Morshin-Nikish. Moskva: Sovetskaya Entsiklopediya, 1974. 616 p. 
literature concerning the subject of philosophy, sociology, historical geography and cybernetics."

Razgon defined museology as a scientific discipline that studied the patterns of the genesis and the development of museums, their social functions and those functions realization in different social order. In his opinion, the subjects of museology were 1) the study of patterns connected with the social conditionality of museums, 2) the study of SPECIFIC sources' aspects that in their order are the basis of museum's activity, 3) specific aspects of nature and social phenomena documented by museum objects. Razgon often quoted Stránský, Beneš, Neustupný and other Czech museologists and pointed out that lots of different aspects of the scientific discipline have already been considered in their works. In one of his articles ${ }^{73}$ he continued Stránský's theoretical work and expanded his understanding of the object and subject of museology. Razgon highlighted Neustupnýs efforts in the development of 2 types of museological research, however from his point of view there were three types of them..$^{74}$ In addition to fundamental and practical research Razgon added the third type that he called "development".

In 1979 USSR participated in the $3^{\text {rd }}$ annual ICOFOM symposium in Torino, Italy, ${ }^{75}$ where they worked closely with Stránský. The themes of the conference included the preparation of the theoretical treatise of museol-

73 In 1981 Razgon sent V. Sofka an article Multidisciplinary research in museology. Fundamental and applied research for the second volume of $\mathrm{Mu}$ seological working papers. DoTraM: Documents de travail sur la museologie, 1981, no. 2. Department of Written Sources The State Historical Museum, file 546 - Personal files A. M. Razgona, cart. 280. Letter from A. Razgon to J. Jelínek on February 22, 1981.

74 See NEUSTUPNÝ, Jiří. Muzeum a věda. Praha: Národní muzeum, 1968. 164 p.

75 Department of Written Sources The State Historical Museum, 546 - Personal files of A. M. Razgon, file 242, sg. 13-15. ogy and ICOFOM's future prospects. Reports by Committee members from Czechoslovakia (Jelínek) and Sweden (V. Sofka) were presented during the session. The Soviet delegation was represented by I. A. Antonova $^{76}$, A. M. Razgon and M. P. Tsukanova. ${ }^{77}$ The focus of the conference belonged to the issues of the definition of museology and the proposed outline of the museological treatise. A special commission made up of A. M. Razgon, V. Sofka and K. Klausewitz was created to tackle them. All of the $3^{\text {rd }}$ session's decisions were negotiated by the specially assembled editorial team.

A. M. Razgon and Y. P. Pishchulin took part in ICOM's International documentation Committee's session on 20-26 February 1983 in Budapest. "The Soviet delegation has maintained close contacts with the representatives of socialist countries especially the museologists from GDR and Czech, SSR." 78

\section{The final resolution of the 9th} General Conference of ICOM in Moscow pointed out the need for the development of scientific museological terminology. According to this resolution scientific terminology national groups were created in many countries of the world while the Institute of Restoration and Museological Methods in Hungary was chosen as the center for the development of the International Dictionary of Terms. The working papers of these national working groups allowed the International Committee for Documentation to create the

\footnotetext{
76 "On the study of a museum visitor. The joint research by the State Museum of the Arts and the psychology and sociology experts."

77 "The museum's place in the social institution system in modern museology."

78 Department of Written Sources The State Historical Museum, 546 - Personal files of A. M. Razgon, file 272, sg. 84, Materials about Razgon's anad Pishchulin's mission to Budapest 20-26, 1983.
}

first version of Dictionarium Museologicum in $1978 .{ }^{79}$

The composition of the USSR delegation was confirmed by the Ministry of Culture ${ }^{80}$ in 1982, the delegation consisted of several leading Soviet museologists including A. M. Razgon, who was the main USSR representative. He along with I. L. Radishchev and Y. P. Pishchulin worked with the ICOM subcommittee on the creation of the Dictionary. The Czechoslovak delegation proposed to change the whole structure of the dictionary, introducing not an alphabetical order but a contents one. The proposal was considered to be interesting but the idea was rejected due to the danger of exceeding the deadline. ${ }^{81}$ The Museological dictionary was published in 1986 in 20 languages. The Czechoslovak working group was created in 1979 and translated Dictionarium Museologicum into Czech in 1982.

The project of the international museological summer school (ISSOM) in Brno was proposed by Stránský in 1983. It was opened in 1986 under the patronage of UNESCO and ICOM. The ideas and principles of education have been adopted by several other countries including Russia. Similar school were organized by I. M. Kozlova in 2002 in Moscow, by O. N. Truevtseva in Siberia, by the director of the "Perm-36" Memorial center of the Political Repressions

\footnotetext{
79 The decision to proceed with the creation "Dictionarium Museologicum" was made at the 9th General Conference of ICOM in 1977.

80 Department of Written Sources The State Historical Museum, 546 - Personal files of A. M. Razgon, file 272. Order from 10. October 1982 on the establishment of the Soviet Committee of ICOM a working group on preparation of the vocabulary of museum terms. The working group included G. G. Popov, I. A. Rodishcheva, A. M. Razgon, V. I. Korchagina, M. B. Pledovskiy, T, G, Igumnova, A. M. Kantor, L. V. Maru, N. A. Mayasova, Y. P. Pishchulin, A. I. Frolova.

81 Department of Written Sources The State Historical Museum, 546 - Personal files of A. M. Razgon, file 272, sg. 60-65. 
History V. A. Shmirov and M. Gnedovsky who had participated in the Brno school themselves.

The first International Museological School organized by ICOM and the Department of History and Museology of BGPU opened its doors in Barnaul in 2007. In 2008 the school had the lectures given by an international team of scientists including H. Vieregg (Germany) and J. Dolák (Czech Republic). Currently the annual schools are organized by the Siberian Committee of Museology.

After the socialist regime fall in 1991 there was a significant decline in the number of international projects and in the cooperation between Czech and Russian museologists. However, the international conferences still encouraged professional contacts between scientists.

The $22^{\text {nd }}$ annual ICOFOM symposium took place in Brno and $\mathrm{Mu}-$ nich in 2000. The Brno conference dedicated to "Museology and the intangible heritage in post-totalitarian countries" attracted representatives from 23 countries, including Russian Federation. In 2008 took place the conference "Museology in the beginning of the $3^{\text {rd }}$ millennium - theory and practice" whose participants tried to address the issues concerning the importance of theoretical museology and its applications to museum practices.

\section{J. Dolák actively cooperates with} Russian museologists. He gave lectures in Saint-Petersburg and was one of the organizers and participants of conferences in 2007, 2008, 2010, 2012 in Russia. But his active participation in the Russian museological practice in the $21^{\text {st }}$ century is an exception to the rule.

\section{CONCLUSION}

The cooperation between Czechoslovak and Soviet scientists resulted in the significant influence on the academic sphere and education in the field of museology. L. M. Shlyakhtina says that “Z. Z. Stránský's interpretation of museology should be the basis of the educational strategies and the museum specialists' training framework at our university." ${ }^{22}$ Stránský's ideas are reflected in all modern museological textbooks.

International cooperation including the exchange of ideas at conferences and the publication of scientific works with support from ICOM and ICOFOM played a significant role in the formation of museology as a scientific discipline.

The cooperation of scientists included the annual symposiums and conferences, joint museological publication projects such as Dictionarium Museologica, literature exchange. The surviving correspondence between A. M. Razgon and Czechoslovak museologists (Jelínek, Stránský, Pubal) makes it possible to state the great interest in their great interest on in each other's research.

Nevertheless there is a serious contradiction in the approach to museology between the Western European and the Eastern European scientists. Czech museologists actively and productively cooperated with Razgon in order to develop museology as a scientific discipline. The discussion of acute problems of museology, many international contacts, museological literature exchange and translation influenced the museological thought in both USSR and Czechoslovakia.

\section{Z. Stránský's theory of museol-} ogy impacted significantly the Soviet museologists' (particularly A. Razgon) understanding of this

82 SHLYAKHTINA, Lyudmila. Strategii muzeevedcheskogo obrazovaniya $\mathrm{v}$ kontekste razvitiya muzeologicheskikh idey In Trudy Sankt-Peterburgskogo gosudarstvennogo universiteta kul'tury i iskusstv. Vol. 200. Spb., 2013, p. 335. young science. Constant study and analysis of Czech museologists' works (Z. Z. Stránský, J. Beneš, J. Neustupný and others) made it possible to form Russian own system of museology similar to Czech one. The works of Stránský, J. Beneš, J. Neustupný are often mentioned in Soviet and Russian textbooks of the late $20^{\text {th }}$-early $21^{\text {st }}$ century. They became the foundation for many researches and influenced the formation of a scientific school of theoretical museology at the Saint-Petersburg State University of Culture. It can be seen from the works of its professors, post-graduate and graduate students.

After the collapse of the Soviet Union and the death of Razgon, Beneš, Jelínek and regretfully after the recent death of one of the most outstanding museologists - Z. Stránský - the contacts between Czech and Russian scientists have declined and have never again reached the level of 1960s-1980s. Eastern European scientists have lost their leading positions in the international organizations. The international dictionary published by ICOM in 2012 haven' $t$ already defined museology as a science.

\section{BIBLIOGRAPHY}

ANANIEV, Vitaly. K 105-letiyu Irzhi Neustupnogo: Neizvestnye pis'ma iz arkhiva Gosudarstvennogo Ermitazha. Muzey, 2010, no. 8, pp. 66-71.

ANANIEV, Vitaly. Istoriya formirovaniya i osnovnye napravleniya deyatel'nosti mezhdunarodnogo byuro muzeev. Vestnik RGGU. Seriya Kul'turologiya. Iskusstvovedenie. Muzeologiya, 2012, vol. 31, no. 11, pp. 224-232.

ANANIEV, Vitaly. Chekhoslovatskaya shkola v muzeologii. In ANAN'YEV, Vitaly G. Istoriya zarubezhnoy muzeologii: uchebno-metodicheskoy posobie. Sankt-Peterburg: Institut istorii S.-Peterb. gos. un-ta, 2014, pp. 68-82.

ANANIEV, Vitaly. Fedor Ivanovich Shmit i sbornik Muzei: Mezhdunarodnoe issledovanie po voprosu reformy publichnykh galerey (1931 g.): u istokov muzeynoy 
revolyutsii. Voprosy muzeologii, 2012, vol. 6, no. 2, pp. 187-193. ISSN 2219-6269.

Archiv Moravského zemského muzea v Brně, file Moravské zemské muzeum (částečně zprac.) - Jelínek, ICOM.

BENEŠ, Josef. Základy muzeologie. Opava: Open Education \& Sciences pro Ústav historie a muzeologie Filozoficko-přírodovědecké fakulty Slezské univerzity, 1997. 179 p. ISBN 978-80-901974-3-5.

Bol'shaya Sovetskaya Entsiklopediya. V 30 t. Vol. 17. Morshin-Nikish. Moskva: Sovetskaya Entsiklopediya, 1974. 616 p.

DENKSTEIN, Vladimír, František MATOUŠ and Karel TUČEK. Musea slouží lidu: Příručka pro musejní a vlastivědné pracovníky. Praha: Orbis, 1954. 129 p.

Department of Written Sources The State Historical Museum, file 546 - Personal files A. M. Razgona.

DOUŠA, Pavel. Organizace českého muzejnictví 1945-1989. Opava: Slezská univerzita v Opavě, Filozoficko-přírodovědecká fakulta, Ústav historie a muzeologie, 2005. 231 p. Ph.D. Thesis.

KAULEN, Mariya. Uchebnik muzeevedeniya kak svyazuyushchee zveno mezhdu teoriey i praktikoy. In MINENKO, G. N. (ed.). Kul'turologiya $v$ teoreticheskom i prikladnom izmereniyakh: Materialy nauch. prakt. seminara. Kemerovo, Moskva: Rossiyskiy institut kul'turologii i Kemrovskiy gos. inst iskusstv i kul'tury, 2001, pp. 254-260.

KIRSCH, Otakar. Association of Museum Workers in Defence Against Counerfeiting and Unfair Trade Practices: comments on the origins of organized meetings of museum workers on an international basis. Museologica Brunensia, 2015 , vol. 4 , no. 2 , pp. 48-55. ISSN 1805-4722.

KUZ'MINA, E. E. (ed.). Muzeevedenie. Muzei mira/Cb. nauch. tr. Moskva: Nauchno-issledovatel'skiy institut kul'tury, 1991. 384 p.

LAQUA, Daniel. Transnational intellectual cooperation, tha League of Nations, and the problem of order. Journal of Global History, 2011, vol. 6, no. 0, pp. 223-247. ISSN 1740-0228.

Mezinárodní anketa. Muzeologické sešity, 1983, vol. 9, pp. 9-55.

Muzeynoe delo: Muzey - kul'tura - obshchestvo: sb. nauch. tr., vyp. 21. Moskva: Izd-vo Muzeya revolyutsii, 1992. 276 p.

Musees/Cahiers de la république des lettres des sciences et des arts. Vol. XII. Paris, 1931. $480 \mathrm{p}$.

NEUSTUPNÝ, Jiří. Muzeum a věda. Praha: Národní muzeum, 1968. 164 p.
Osnovy sovetskogo muzeevedeniya. Moskva: Gosudarstvennoe izdatel'stvo kul'turno-prosvetitel'skoy literatury, 1955. 375 p.

NEUSTUPNÝ, Jiří. Otázky dnešního musejnictví: př́spěvky k obecné a speciální museologii. Praha: Orbis, 1950. 206 p.

PUBAL, Václav. Kabinet musejní a vlastivědné práce. Časopis Národního muzea, 1957, vol. 126, no. 2, p. 231.

Rossiyskaya muzeynaya entsiklopediya [online]. Moskva, 2002 [cit. 2016-01-28]. Available from www: <http://www. museum.ru/rme/>.

SHLYAKHTINA, Lyudmila. Strategii muzeevedcheskogo obrazovaniya v kontekste razvitiya muzeologicheskikh idey. In Trudy Sankt-Peterburgskogo gosudarstvennogo universiteta kul'tury i iskusstv, 2013, vol. 200. Spb., pp. 332-338.

STRÁNSKÝ, Zbyněk Z. Archeologie a muzeologie. Brno: Masarykova univerzita v Brně, 2005. 315 p. ISBN 978-80-210-3861-5.

STRÁNSKÝ, Zbyněk Z. Podstata muzeologie a její zařazení do vysokoškolského studia In Sborník materiálů prvého muzeologického sympozia. Brno: Moravské muzeum, 1966, pp. 10-17.

ŠPÉT, Jiří. Muzea ve vývoji společnosti a národní kultury. Praha: Národní muzeum, 1979. $279 \mathrm{p}$.

TRUEVTSEV, Nikolay. Istoriya obrazovaniya i deyatel'nost" komiteta muzeologii mezhdunarodnogo soveta. Barnaul: FGBOU VPO, Altayskaya gosudarstvennaya pedagogicheskaya akademiya, 2012. 214 p.

VAN MENSCH, Peter. K metodologii muzeologii (perevod s angl. yaz. V. G. Ananieva). Voprosy muzeologii, 2014, vol. 9, no. 1, pp. 15-291 [online]. [cit. 2015-08-22] Available from www: <http://cyberleninka.ru/journal/n/voprosy-muzeologii > ISSN 2219-6269.

YURENEVA, Tamara. Muzeevedenie: uchebnik dlya vysshey shkoly. Moskva: Akademicheskiy Proekt; Al'ma Mater, 2007. 560 p.

\section{MARIA GUBARENKO}

Katedra muzeologii i kul'turnogo naslediya Sankt-Peterburgskogo gosudarstvennogo instituta kul'tury Sankt-Peterburg

Rossiyskaya Federatsiya

gubarenkomaria@gmail.com

Maria Gubarenko, fine art restorer of wallpaintings, graduated from the Faculty of Restoration Studio of Restoration and Conservation of Wall Painting and Sgraffito University of Parbubice (Bachelor of Arts) in Litomyšl. At the moment she

lives in Moscow and works in the field of restoration and protection of monuments of culture and art. In 2016 received a master's degree in museology and cultural heritage (Saint-Petersburg State University of Culture). She has participated in the restoration of many monuments in the Czech Republic, in Slovakia and in Russia, took part in a lot of international conferences and workshops, the author of scientific articles.

Maria Gubarenko je restaurátorkou nástěnných maleb. Vystudovala v Ateliéru restaurování nástěnné malby a sgrafita na Fakultě restaurování Univerzity Pardubice (bakalář umění) v Litomyšli. V současné době žije v Moskvě a pracuje v oboru restaurování a ochrany kulturních a uměleckých památek. $\mathrm{V}$ roce 2016 ukončila magisterské studium muzeologie a kulturního dědictví (Petrohradská státní univerzita kultury a umění). Podílela se na restaurování mnoha památek v České republice, na Slovensku a v Rusku, účastnila se velkého množství mezinárodních konferencí a workshopi̊ a je autorkou vědeckých článků. 